\title{
Money for climate
}

\section{A judicious use of financial instruments today could protect the well-being of future societies but investment and ambition needs to rapidly increase to achieve this outcome.}

Climate change is already causing impacts through changes in the mean state and extremes - these require action to minimize the impacts to society. As a consequence, scholars and policymakers recognized the need for an increased attention to financial instruments specifically dedicated to actions and projects that should control climate change impacts. Climate finance - the set of financial instruments and monetary flows that support mitigation and adaptation activities - is a key part of the Paris Agreement. The Green Climate Fund, first proposed in 2009 at COP15 Copenhagen and in operation since 2014, is one key instrument (www.greenclimate.fund).

There are a variety of sources that can fund climate finance; the public ones include government-allocated funding often derived from carbon taxes and the revenues of carbon markets. Carbon taxes are a market-based approach where a limited number of permits are sold; companies and other economic actors are required to hold permits in an amount equal to their $\mathrm{CO}_{2}$ emissions. This mechanism favours investments in low-emission technologies, in order to reduce spending on permits. As illustrated by Ottmar Edenhofer and colleagues in a Commentary (page 463), carbon pricing is in place, or being considered, in many states and countries around the world. However, it's not a perfect solution as low-income households may bear a higher burden because of disproportionate consumption of carbon-intensive goods relative to income. Distributing the revenue of the carbon prices through social transfer could alleviate the problem.

Climate finance from public funds is projected to increase to US $\$ 66.8$ billion by $2020^{1}$, with additional funding expected to come from the private sector. At the April 2017 Green Climate Fund board meeting eight new projects were approved valued at US\$755 million, ranging from hydropower resilience in Tajikistan to ground water recharge and irrigation to ensure food security in Odisha, India. This brings the total projects to 43 , with US $\$ 2.2$ billion coming from the Green Climate Fund, and additional funding from co-financing raises the total to
US $\$ 7.3$ billion. Co-financing is an essential component of the Green Climate Fund, with a target of US $\$ 100$ billion by 2020 coming from public and private sources.

Private investment is important to climate finance - in May 2017 the World Bank announced a commitment to increase climate finance to $28 \%$ of its portfolio by 2020; another example is the European Bank for Reconstruction and Development, a multilateral development bank, with a 2020 target of $40 \%$, up from $25 \%$ over the last 5 years. Multilateral development banks work with Climate Investment Funds (www.climateinvestmentfunds.org) to support 72 developing countries working towards low-carbon, climate-resilient development. Recently, Innovate4Climate (www.innovate4climate.com) was held in Barcelona, the first of what looks to become an annual event, bringing together finance, markets and technology sectors to promote climate action. It was at this event that the Green Climate Fund launched a call for proposals aimed at leveraging private investment (www.greenclimate.fund/500m).

Green bonds are one way in which private markets finance environmental initiatives. In early June 2017, Apple announced a US\$1 billion bond, following from its US $\$ 1.5$ billion first green bond in 2016. 2016 saw green bonds to the value of US\$81 billion issued, a small proportion of the whole bond market but a doubling of those issued in 2015. Topping the list was the Bank of China with a US $\$ 3$ billion offering $^{2}$, with strong increases from other Chinese banks. For 2017 it is estimated US $\$ 150$ billion worth of green bonds will be issued (www.climatebonds.net), providing essential climate funding.

It is heartening to see the shift in public and private commitment to green finance, but is it enough? Currently climate finance focuses on adaptation and mitigation; however, loss and damage is another climate change concept that has been overlooked in this field. Cost estimates for loss and damage, specifically climatechange-related loss of land and culture or forced migration, total US $\$ 50$ billion a year by $2020^{3}$ (and are rising rapidly with an estimated minimum of US $\$ 300$ billion

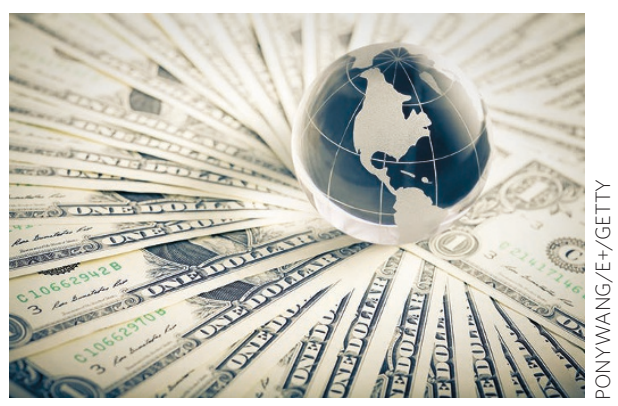

a year by 2030). These are in addition to the estimated costs of mitigation and adaptation, indicating a rethink is needed on sourcing funds for climate finance.

In 2013, the World Economic Forum estimated US\$5.7 trillion will be needed annually by 2020 for green infrastructure ${ }^{4}$. The report suggests that public funds would need to increase to US\$130 billion, an increase over the Green Climate Fund target of US $\$ 100$ billion, to leverage US $\$ 570$ billion of private capital. Currently the Green Climate Fund has pledges of just over US $\$ 10$ billion and United States withdrawal may decrease this by US $\$ 2$ billion, highlighting a gap between what is needed and what is currently happening. An alternative estimate ${ }^{5}$ suggests resilience investment in 2035 needs to be US $\$ 200$ billion to avoid losses of US\$1 trillion. Currently, a widening gap between investment and climate damage costs suggests there will be a funding shortfall of US $\$ 130$ billion.

Progress is being made in green bonds and climate finance, but as is the case with emissions pledges the current levels are not enough to meet the aspirational targets. A shift in thinking and rapid action is need to close the gap between what is happening now and what is needed to mitigate the impacts of climate change.

\footnotetext{
References

1. 2020 Projections of Climate Finance Towards the USD 100 Billion Goal Technical Note (OECD, 2016).

2. Weinland, D. Bank of China issues $\$ 3 \mathrm{bn}$ in international green bonds. Financial Times (6 July 2016).

3. Richards, J.-A. \& Schalatek, L. Financing Loss and Damage: A Look at Goverance and Implementation Options (Heinrich Böll Stiftung, 2017).

4. The Green Investment Report: the Ways and Means to Unlock Private Finance for Green Growth (World Economic Forum, 2013). 5. Climate Change and Business Survival: the Need for Innovation in Delivering Climate Resilience (Mott MacDonald, 2015).
} 